\title{
Minor if Entertaining Post-Utopian Nowheres
}

\author{
ANNE LAKE PRESCOTT \\ Barnard College, Columbia University
}

\begin{abstract}
Not all utopias are truly imaginative, yet minor ones can be instructive or amusing. This article explores the hierarchy-obsessed French Antangil as well as some minor English ones so as to deduce further what so entranced so many about Nowhere's possibilities. None is as radical as Utopia itself-nor as intelligent. They do, however, show the uses to which a "utopia" can be put. After a glance at Antangil this article moves to a letter from the king of Utopia and thence to Edward Howard's royalist drama Six Days in a New Utopia (1671), an interesting failure on stage. After a few glances at other utopias the article ends with a grimly amusing avian debate concerning the desire of foreign (French) canaries to settle in Utopia (England), where they will be safe from a persecutory eagle (Louis XIV). Utopia is "nowhere," but it is a useful nowhere.
\end{abstract}

Les utopies ne sont pas toutes véritablement originales, toutefois certaines peuvent être instructives et amusantes. Cette étude explore l'Antangil, un ouvrage français obsédé par la hiérarchie, ainsi qu'un certain nombre d'ouvrages mineurs anglais, dans le but de mieux comprendre ce qui a séduit tant de lecteurs dans les possibilités d'un "Nulle part». Aucune de ces ouvres n'est aussi radicale que l'Utopie de More elle-même, ni aussi intelligente. Elles montrent cependant quelle peut être la fonction de telles utopies. Cette étude, après avoir considéré l'Antangil, se penche sur une lettre du roi d'Utopia, et sur le drame royaliste Six Days in a New Utopia d'Edward Howard (1671) ayant eu curieusement peu de succès sur scène. Après avoir survolé quelques autres textes similaires, on termine notre examen avec un amusant débat aviaire traitant du désir de canaris étrangers (français) de s'installer en Utopie (Angleterre), où ils seront à l'abris de la persécution d'un certain aigle (Louis XIV). On y constate qu'Utopie est un "nulle part", mais un "nulle part» utile.

$\mathrm{T}$ his article describes some usually neglected if not always impressive utopias that make part of Thomas More's complex earthly afterlife. Indeed, the very conference from which the articles in this volume derive is a reminder of how much that afterlife fascinates us. True, Utopia's progeny are not always what More's traveller, Raphael Hythloday, might have admired. Some years ago, I performed a Google search for Utopia's offspring and turned up a game called "Utopia" in which barons compete to see how many serfs they can accumulate-one can only imagine Hythloday's expression if told about this. A more recent search yielded exactly 58,900,000 hits, a number that at least has many good zeros, if not Outopias. More genuinely useful to a thinking about zero and More's Utopia, though, is a study by the modern mathematician 
Andrew Simoson, who examines the island's geography as described in the 1516 text and the maps printed with early editions of Utopia. These maps show not a perfect circle but an oval, a shape that may go well with the text's irony and complexity; near one end of the oval is a nice circular lake. ${ }^{1}$ More's worldly afterlife, then, has not been thin or featureless, and indeed a modern search of Early English Books Online produced at least 1,147 hits in 655 records before 1700 , although one does get tired of the use of "utopia" as a place to put ideas or plans that an author finds hard to believe-or would want to find impossible. Some longer and printed moments in St. Thomas's afterlife have received scholarly attention, but others are beyond obscure. Many readers might find these latter amusing, although they would hardly be required reading in any sensible course on utopias.

I begin, although violating chronology, with what the few who write about it call the first French book-length utopia, the Protestant Antangil (1616) by the so far unidentified "I.D.M.G.T." The first printings are associated with Holland and with the then largely Huguenot city, Saumur, where the great Philippe du Plessis-Mornay was long governor; the printer, Thomas Portau, was one of Mornay's protégés. The French had long admired Utopia, which had of course been printed first on the Continent, and, although this can be easy to forget because he seems so French (if gigantic), Rabelais's Gargantua is king of Utopia, and Utopian is one of the few languages that his son Pantagruel recognizes when he first meets the trickster Panurge and the latter speaks in all sorts of tongues. Indeed, many call Rabelais's Abbey of Thélème a utopia, although I have doubts-no co-ed abbey that would reject Socrates (too old and ugly) or Rabelais himself (hardly young and handsome) should qualify as a Morean utopia.

Antangil owes much to More, if showing his Utopia in a distorting mirror that in some ways turns Hythloday's report upside down and backward. Although we are not sure of the author himself (the slight if intelligent scholarship on the text has no consensus), he is clearly Protestant as well as royalist. ${ }^{2}$ This work

1. See Andrew Simoson, “The Size and Shape of Utopia," published with illustrations in the Briges Finland Conference Proceedings (2016), 67-70; see http://archive.bridgesmathart.org/2016/bridges2016-65. pdf. I thank Prof. Simoson for replying to my queries.

2. See Denis D. Grélé, “Travail et Justice au royaume d'Antangil (1616),” Proceedings of the Western Society for French History 31 (2003): 1-16, useful on economics and taxes, and Frank Lestringant, "Huguenot en Utopie, ou Le genre utopique et la Réforme (XVIe-XVIIIe siècles)," Bulletin de la Société de L'Histoire du 
should interest anyone tracing utopias, although it might irritate those who even partly envy the Utopians' rejection of rank and splendour. Bernie Sanders of recent American memory would not admire Antangil. Edmund Burke, if swallowing hard at some details, just might.

Antangil is not a first-hand report-it has no Raphael Hythloday-but is rather a second-hand account based on conversations with a Dutch seacaptain who has visited Southeast Asia in the neighbourhood of ... Indonesia, perhaps, but closer to the South Pole. The book has five sections, one telling of the island's geography: it is very big, with a variety of latitudes and hence, as ancient medical theory would suggest, producing varied temperaments. Its political and social structures are relentlessly hierarchical, but with positions open to talent and an elective monarchy like, some might say, France's Fifth Republic, even if Antangil's head of state is elected for life. Next comes the military, hugely significant with practices that might depress More's Utopians; then education, with dorms, live-in-faculty, no graduation until the age of twenty-four, courses fitting each of three stages, and post-grad training in various lines of work leading to a future in helping run the country. Last, religion: Christian, hierarchical in many regards but, thanks to the martyred and I assume imaginary St. Byrachil, an Asian disciple of St. Thomas, with only two sacraments (as Luther and Calvin insisted); buildings are free of those supposedly ridiculous idols and superstitions that citizens of Antangil think pagan but that readers would recognize as Roman Catholic. Unlike Luther and Calvin, though, citizens of Antangil affirm the freedom of the will.

Antangil lacks private property as we know it, although there is money, with a tax situation too contradictory for this reader fully to grasp but clearly meant to be fair and minimal; the economy is hierarchical and the author spells out who gets what salary, with little allowance made-as is typical of early utopias (and this may matter, although Francis Bacon's New Atlantis is an exception)for technological shifts, inflation, or population growth. This is, moreover, a very rich kingdom, and although the author has evidently read More's Utopia he is almost parodically (although with no hint that he is intentionally so) charmed by gold and precious stones. Antangil is rich in resources, wonderfully fertile, with many streams and rivers, but it also abounds with what European

Protestantisme Français 146.2 (2000): 253-306. Both are helpful on how Antangil, whatever its focus on hierarchy, fits the utopian mode. I quote the online 1616 edition. 
nations longed for in the way of metals and gems. Not for this author would be the Utopians' quasi-satirical use of gold for chamber pots and slave-chains or of jewels as children's toys-More's carnival reversal of England, of course, but with serious implications. Antangil's leaders, who are elected, not born, to the job, love to hunt, to dine well, and to live in a splendour outdoing that of the Louvre or even, perhaps, that of the future Versailles. Above all, they dress well, beautifully, gloriously. Indeed, if there is one aspect of Antangil that needs stress it is the author's most unUtopian obsession with relating costume to rank. Yes: if you are smart and get into the official boarding schools you too can play a role in administering or protecting the nation and wear those dazzling clothes. But the author's meticulous, some might say obsessive, regard for the details of rank-based costumes remains astonishing; Utopians would gasp, or laugh. Louis XIV himself would be astounded by the costumes, and Marie Antoinette could have ten diamond necklaces, no questions asked.

Treason is imaginable, however, and punishments severe. There are lawyers, too (Utopians would scoff), although not slithery ones. And soldiers, soldiers, soldiers-ranks upon ranks, with astoundingly rich weapons, and with an intense regard for glory and honour. In traditional anthropological terms, this is a shame culture, not a guilt culture-more Klingon than human, Star Trek fans might say. No cards or dice (Hythloday would nod and smile), but grabbing booty after military victory is allowed, and of course it is then divided according to rank. No wives are there in battle to urge on their spouses, a detail in More's Utopia that, I assume, heterosexualizes a scene in Plato's Symposium suggesting that male soldiers fight more bravely with their male beloveds on the scene. The boys' boarding schools have an obsession with costume, although there are statues of naked ladies in the school gardens. True, there is no inherited class system of the European sort (although those in modern democracies know well the personal advantage of having rich and well-regarded parents), but the sharp, indeed obsessional, focus on rank-related details of dress, not least for the clergy, remains almost disturbing-and insufficiently explored, I would argue, by those very few who write on Antangil.

Antangil appeared as yet more clouds were gathering in a France recently shaken by the assassination of Henri IV and by yet more civil and religious tensions. The book's stress on order may thus be advisory, even if one can nevertheless imagine the original Utopians' dismay at (or contempt for) such 
privileged albeit coherent splendour. And Utopian women, although not as equal to men as in our own culture, have a little more equality.

Should students of utopias read Antangil? Of course, if only-and this matters-to see how utopian thought, not just dystopian, can be so relentlessly, so unMorean-ly, focused on social layering and class-related costumes. This is Brave New World by somebody who likes colour-coded class, although nobody in Antangil sorts out and modifies fetuses before their birth as in Huxley's dystopia. Antangil is not alone, of course, in stressing rank, class, and vertical differentiations, even while denying birth's power to determine such variety, but the sheer degree of its fascination remains curious, and so far as I can hear, without parody. More has some distinctions, of course, and some costumes, but nothing like this-Antangil is evidence that we can abolish inherited private property yet still have wealth and visible indications of worldly success.

I turn now to England and, if only for the reader's entertainment, to several obscure examples of Utopia's afterlife; obscure, yes, although academics, utopia-lovers, and readers of this volume may of course have looked at them. They offer yet another indication of the degree to which More's no/nice place grabbed the imagination and proved useful, whether as serious suggestion or political satire. ${ }^{3}$ Like More, William Bullein imagined a reversed England, offering in the 1573 edition of A Dialogue bothe pleasaunte and pietifull a brief dialogue about a much improved capital called "Nodnol," chief city of "Taerg Niatirb." Nodnol's name looks backward, but it is more pious and well behaved than "London," being free of Roman superstition and wicked lawyers as well as much given to church-going. Alas, though, the speaker who describes Nodnol to Civis [citizen] is named "Mendax," or "Liar," so perhaps we should believe him no more than we do that "Nonsense-speaker," Hythloday. Mendax also

3. Jackson C. Boswell, Sir Thomas More in the English Renaissance: An Annotated Catalogue, intro. Anne Lake Prescott, Medieval and Renaissance Texts and Studies 83 (Binghamton, NY: Medieval and Renaissance Texts and Studies, 1994); the collection stops in 1640. My own search, conducted for an essay on More (Anne Lake Prescott, "Afterlives," in The Cambridge Companion to Thomas More, ed. George Logan [Cambridge: Cambridge University Press, 265-87]), relies heavily on Early English Books Online and Eighteenth Century Collections Online.

4. See, though, Elizabeth McCutcheon, "William Bullein's Dialogue Against the Fever Pestilence: A Sixteenth-Century Anatomy," in Miscellanea Moreana: Essays for Germain Marchadour, ed. Clare Murphy, Henri Gibaud, and Mario A. Di Cesare (Binghamton, NY: Medieval and Renaissance Texts and Studies, 1989), 341-59. 
describes seeing some of the traditional monstrous races that Desdemona says Othello told her about; this text, which slides into the utopian genre only part way through the conversation and deserts it when reporting on monsters of the sort that Morus explicitly says he does not wish to hear about, is probably worth a Shakespearean's glance.

One of the best reversed/parodic Englands, though, is Bishop Joseph Hall's Mundus Alter et Idem (1605), translated in 1609 by John Healey, a deservedly better-known text that describes realms set in the Antipodes. These lands, which are indeed "same" and not just "other," include a land governed by women, for example, and another governed by the fat; one portly politician, campaigning to be mayor, claims in ways that may strike some as all too American and possibly Canadian, that "he would preserve us as we were now and make us as we would be." ${ }^{5}$ Indeed. Those who like less parodic utopian suggestions, though, might enjoy, as perhaps the reader has already, the 1641 Description of the Famous Kingdome of Macaria by one "Gabriel Plattes" (probably not Samuel Hartlib, as we used to think), a brief dialogue that claims to have as its "pattern Sir Thomas Moore, and Sir Francis Bacon" (A2v). The civil wars will break out soon, but at the moment Britain is at peace with itself. Plattes makes sensible suggestions about farming, fishing, trade, and "planting"-i.e., colonizingalthough offering nothing on gender, let alone race (not even a glance at the Irish, then thought a distinct race). Indeed, the text is so sensible that perhaps it should not count as fully utopian. Many might envy its suggested top tax rate of five percent, if not the discouragement of religious pluralism-in this regard Macaria is quite unlike Utopia, even if More, in his later years and on behalf of a different version of Christianity, would share the Macarians' desire for religious uniformity. True, one is allowed to argue annually in front of Parliament for revisions to the official creed. Poverty? Those who work hard will be rich, we read. (One often hears that in my own United States of Utopia.) When the speakers agree to "goe into Moore fields" (A3v) to escape the crowds and have a quiet talk, is there another allusion to Thomas More? In any case, the stress is on rational government, including five departments or ministries, as we would call them, that attend to farming, fishing, land trade, maritime

5. See Another World and Yet the Same, trans. John Millar Wands (New Haven: Yale University Press, 1981), with a useful introduction; I quote, for its energy, the 1609 translation by John Healey, E2v. I ignore, for it has received somewhat more attention, Henry Neville's 1668 Isle of Pines, ed. John Sheckter (Burlington, VT: Ashgate, 2011). 
trade, and arranging "new Plantations." There are official efforts to find new medications. Those in the government "live in great honour and riches, and the people doe live in great plenty, prosperitie, health, peace, and happinesse" $(\mathrm{A} 3 \mathrm{v})$. Enviable, but notice that those in the government have honour and great wealth-as in almost all of these minor utopias, and for that matter as in those invented by Bacon, Campanella, and some more significant utopiamakers. Vertical arrangements, layering, and distinctions fascinate these authors, not least the creator of Antangil, even more than they did More. Oh, and innovations, not least print, will spread, says Plattes, and make England even happier. Intriguingly, the scholar in the dialogue reports that "I have read over Sr. Thomas Mores Utopia, and my Lord Bacons New Atlantis, [...] but none of them giveth mee satisfaction, how the Kingdome of England may be happy, so much as this discourse, which is briefe and pithy, and easie to be effected, if all men be willing" (B3). Nicely said, but all men will have to rely on the hope of wealth if they work hard and are willing to watch their government be superbly wealthy. Again, Macaria is a layered society, like so many early modern utopias, but the author's focus is on wealth-producing means of production; there is little here on costumes, for example, or on education.

For those who relish reading epistles from the mighty, I should also mention the brief and anonymous King of Utopia His Letter to the Citizens of Cosmopolis, the Metropolitan City of Utopia. The last page says the text was "Printed at Cosmopolis in the yeare 7641 And reprinted at London An: Dom: 1647," here translated, reports the title-page, into "broken English," and now published together with the loyal citizens' polite reply praising monarchy. By now the British civil wars were in full fury, so unsurprisingly the list of printers' misprints (citing imaginary pages, of course) says snarkily: "for Tyranny, read Taxations," for "Common-wealth read Committee," for "Service read Sacriledge," for "Bishop read Presbyter," for "Pulpit read Tub" (Puritans supposedly used tubs as pick-up pulpits and reputedly would bang them excitedly), and for "Preaching read Prating"-i.e., emitting Puritan blather. The praters and tubthumpers were, of course, trying to establish their own semi-utopia.

That semi-utopia failed, although efforts to found a godly nation continued in Massachusetts. Then, in 1660, came the monarchy's and Church of England's Restoration, and a decade after that, at the Duke of York's Theatre, there arrived a truly obscure play, The Six Days Adventure, or, The New Utopia (1671), which I describe at some length for the reader's perhaps amused 
shudders. I have seen virtually nothing written on it, and even that close-tonothing can be inaccurate. At least the play shows how useful nowhere can be, even in the very this-worldly Restoration. Six Days bombed, to the grinning scorn of the reigning wits, the sort who were still skewering the author with pointed couplets decades later. Despite its failure, however, it was printed that same year with consoling liminary poems, one by the celebrated Aphra Behn, and a defensive but thoughtful preface by Howard himself. ${ }^{6}$ Nor is Howard's imagination remotely utopian. The play does imagine a reversal, but we see only sophisticated aristocrats, together with a few respectable "citizens," and at the end we are reminded that the optimum state of a commonweal is monarchical-a happy ending for those still aghast at the recent Commonwealth.

I doubt many have read this play, so let me describe it at some length, together with evidence of the scorn it drew, and then suggest why it might nevertheless interest anyone tracing exploitations of the word and concept "utopia." The play is set in Utopia, evidently Thomas More's imaginary island but filled with clever gentlemen and ladies, these last determined to take advantage of what we hear is an ancient Utopian law requiring the periodic rule by women. (Yes-Hythloday forgot to mention this.) There is no popular rebellion, no wives withholding sexual favour as in the Greek Lysistrata, and no Queen Utopa to oversee this reversal. Howard does want us to remember England's recent upending, though, for one of his characters, "Sir Grave Solymour," is modelled on those supposedly pleasure-hating and solemnly grave "Puritans" who had abolished kings and stage plays, and one character calls his native Utopia a "monstrous Democracy." Yet in the play itself the reversal is meant to accord with ancient laws, not to overthrow them. ${ }^{8}$ Indeed, we barely see the populace,

6. The entry on Howard in the Oxford Dictionary of National Biography errs, I think, in calling this play "Partly based on Ben Jonson" (ODNB, accessed June 2018, http://www.oxforddnb.com), although in his preface Howard praises Jonson and to some extent may write "humors comedy." Robert Appelbaum's admirable Literature and Utopian Politics in Seventeenth-Century England (Cambridge: Cambridge University Press, 2002), 214-15 mischaracterizes the plot of A Six Days Adventure, or, The New Utopia as entailing a citizens' "rebellion," calls the result a reversed "sexual democracy" (surely women's rule is no more "democratic" than men's), and implies, without evidence, that the play saw a number of performances.

7. Act 4 (all acts have but one scene); sig. H1.

8. True, Sir Solymour refers to his female-run country as an "anti-Utopia" (act 4, p. 55). He means, of course, that female rule is a very bad idea indeed, but the word in this context is conceptually confusing if subjected to some pressure: to the extent that "utopia" had come to mean an impossible ideal, such a 
let alone anyone who explains the economic system, the costumes, the penal code, and so forth. The only alter we witness is the decision to give women their turn at rule; everything else is idem. Unlike More's Utopians, moreover, Howard has little use for modern scientific experiment, although we should admire any writer who names a chemist "Orlando Curioso." Are we meant to recall the Royal Society?

In the opening scene we meet solemn Solymour, despiser of music and seeker of reformation. He is asked by merry Mr. Merideth, "what call you Reformation?" Solymour answers, "The suppression of vanity and vice," and Merideth replies in turn that "I have heard of such a Sect in England", one "that says the same but behaves far otherwise (B2; royalists such as Howard liked to imagine the enemy as both fanatic and hypocritical). This Utopia is not, then, the real England's ambiguous or parodic other, at least aside from the hint that in Howard's own nation women do in fact have too much influence, not least near the throne.

Soon we hear more about the new shift in gendered power. Solymour worries that "we are this day in danger / Of being unmann'd," and Meredith nervously "Feels below," one of the play's many sexual jokes (B2v). One Mr. Frankman, at least, looks forward to the "Novelty" of seeing women compete for "beauty, place, and superintendency." Yes, says Meredith, it will be "so sportive, and aery, that an Anarchy under them / Would be pleasant" (B3). After some anti-female remarks by the almost lunatic cavalier Mr. Foppering, we meet $\mathrm{Mr}$. Peacock, a narcissist dressed in feathers who likes to molt bits of French into his conversation (a common practice in Restoration comedy and the object of satire). Then we hear from the Utopian officials who agree to "have women Magistrates [who] in order / Of nature should be our subjects" (C2v). The results are dismaying to some, and Foppering exclaims that women turning men are "using of their vigours the wrong way [...] I saw at least a dozen uppermost with men under them, / Who lay as flat as flounders" (C3; many women reading this might reflect that they seem to have escaped flattening, i.e., flounderization, despite making love in the most common position). All is disorder, and women are beating their husbands. Solymour can only ask "What a Moon of madness are we come to?" (C3). Moons of course are lunatic-and female.

commonweal would, if truly optimal, have male dominance; on the other hand, if a utopia is a parodic reversal of the familiar norm, then female dominance would make sense as satire (Englishwomen have no rule, literally, but they have too much power in fact) and would not require an "anti." 
In act 2, to be sure, one magistrate suggests that women have long "been in full command, / Already," for this play is divided between imagining a new nowhere-utopian female takeover and rehearsing the old joke that women do in fact run the show. Once again, alter and idem get muddled. And the offcolour jokes continue-women are like slippery eels, says Solymour, because you cannot take them by the ... um, ... tail. Maybe we should have joint rule? Or we men could govern by day and the ladies by night? No, women demand the full rule that the law requires. Maybe, says Merideth, it will be fun.

At this point we hear of a subplot that supplements and modifies the play's fairly timid exploration of gender. Peacock has been reading Ovid's story of the self-infatuated Narcissus, has gazed at himself in the mirror, and is in love with what he sees there. Now he has visited the Paracelsian Mr. Curioso, the play's anti-Robert Boyle or non-Newton, hoping that the scientist can extract Peacock's own self so he can make love to that now separate same/other, something Narcissus himself never achieved, despite long reflection. ${ }^{9}$ Soon we meet the now dominant ladies, who start, with many a moon and horns joke, to order the men around sexually (but not economically-this play is about sex, not money). They agree to retain the form of a republic, and they receive from a group of citizens "a Mace, Sword and Charter" (E2). If there is a war, the ladies agree, they themselves will lead the troops into battle.

In act 3 there is a new subplot involving Solymour and his long-neglected son, but the most stunning development concerns the self-amorous Peacock, who has now visited the learned Curioso and been what we would call cloned-Peacock's inner other is now outside-a mundus multiplied? Inversed? Literally both alter and idem? Soon he re-enters the stage, passionately kissing and hugging a man he thinks is his now-externalized inner other self; yes, on the stage this would send out vibes useful to anyone tracing the history of homosexuality. Indeed, one might usefully compare the scene to John Donne's Lesbian poem "Sapho to Philaenis," likewise concerned with same and other.

In the main plot the women decree the end to male sexual advances, now the prerogative of women. Crispina explains that "there is some state in restraining the bold Presumptions of men" (G2v), but the move also has ancestral cousinship with such anti-Utopias as George Orwell's 1984 or

9. Orlando Curioso lives near a street or neighbourhood named "the Labour $\operatorname{In}[\mathrm{n}]$ vain." It is hard to determine if this subplot, which stages mutual kissing by two men who are also, for the credulous or imaginative, the same man, belongs to the history of attitudes to homosexuality or to masturbation. 
Yevgeny Zamiatin's We, in which the more personal and subjective forms of eros are suppressed or channelled by the state. Little is more personal than our sexual fantasies or desires, so it is not surprising that only the more courageous utopias engage the topic; More at least-and this was one of his book's most noticed features-imagined the sexual curiosity that can be satisfied by seeing one's fiancé[e] naked. The ladies in Howard's Utopia will, we hear, even make a list of which men are fit to make love, marry, or "continue still Platonicks" (G3v, an early misuse of "platonic" that one might file with misunderstandings of "utopian" as "perfect"). In act 4, one man even wonders nervously, or ironically, if the new regime will now make "a Jury of / Women with Spectacles commission'd to make a survey of / Us naked" (G4). Now that is a practice that More's Utopians might actually like. A friend replies dejectedly that "There's no superiority to be expected but lying uppermost, / And that I suppose they will allow us" (G4v). How conventional!

Now come more new laws: only women may make amorous approaches, while men must wait to be asked and are forbidden "Lovers Oaths, and Perjuries" (H1v). And another subplot: Sir Solymour tries to make love to one of the ladies, Celinda, tossing off his gown and attempting to slip into her bed, only to be interrupted by a lady "Moor" who declares her love for Solymour and seemingly has a legal claim on him as his wife. Not to worry, some friends tell him-African women are famously good in bed and he could even have a magpie-coloured child; yes, racial stereotyping and ignorance, if not quite denigration.

Act 5 opens with "a Tribunal of Love" as the female governors try to decide which gentleman fits which erotic category. Poor Merideth is horrified to be listed as a "Platonick," a category he considers an "affront to flesh and blood of mine" (L1v), and when two ladies each want the many-gifted Polidor, one exclaims, "This sounds too much of Anarchy in love, the worst / Of mischiefs to all humane government" (K3). Again, and hardly for the last time, sexuality exists in tension with utopian (or dystopian) organization. But solutions arrive. The men now realize that if only women may make the first move, then men can seize the ancient female prerogative-refusal. So now gentlemen will refuse all female advances, even if accompanied by encomia to their eyes, hands, and periwigs. Indeed, they will quit Utopia altogether, leaving behind no males over sixteen. The subplots are resolved (Peacock learns he has been had and sheds his feathers; the Moorish lady reveals herself as a boy; Solymour reconciles 
with his son) and now someone remembers that Polidor has royal blood. The solution is clear: "citizens" and ladies welcome "this most happy end / Of both republics" (presumably both the usual Utopian male-dominated one and the recent period of female rule) as Polidor is declared king (a rex ex machina, suggests a friend of mine) and takes Serina as his queen. Equality? Hardly. The new king has the last word:

Nature has made for men her Salique-Law

Given Women to continue men, not govern,

And though both Sexes here have held Republicks

(A usage different from all other Countreys)

In each example they may wisely see

No rule's so good as lawful Monarchy (M2v).

This is an allusion, of course, to the French "Salic Law" forbidding female rule; wrongly thought ancient, it mandated that Queen "Margot," daughter of Henri II, could never inherit the throne after her brothers all died. Has Howard forgotten Mary Tudor and Elizabeth?

The play flopped, its author long the object of laughing contempt. Some contempt was probably personal, for Howard seems to have been irritatingly arrogant, but a more serious reason, his defensive preface implies, was his presumed failure to imitate natural human behaviour and manners: his wit is all fancy and no judgment. ${ }^{10}$ A poem by Charles Sackville, Earl of Dorset, calls the author "Thou damn'd antipodes to common sense!" and asks whence "Does all this mighty stock of dullness spring, / Which in such loads thou to the stage dost bring?" Men should keep pens out of his hands much as we keep knives and razors, and in fact the paper on which his Muse inspires him to scribble would do better "To wipe the slav'rings of her infant wit." Yes, vivid. ${ }^{11}$ In his 1679 "Essay upon Satire," the Earl Wilmot of Rochester scoffed at him (a fact noted in several eighteenth-century encyclopedias), as did John Dryden's

10. On these terms and on Restoration dramatic theories, see Robert D. Hume, "Theory of Comedy in the Restoration," MP 70.4 (1973): 302-18. Hume quotes Howard's preface to Six Dayes.

11. The Poems of Charles Sackville, Sixth Earl of Dorset, ed. Brice Harris (New York: Garland, 1979), 15-17. Howard's plays are so bad, we read, that one might think them "translated out of Dutch." This is no mere xenophobia, for the Dutch were at this point rivals of Britain. 
victim, Thomas Shadwell. ${ }^{12}$ Pope's Dunciad imagines the magna mater Dullness, opiates in hand, welcoming bad poets into an Elysium "Safe, where no critics damn, no duns molest, / Where Gildon, Banks, and high-born Howard rest."13 A fictionalized Howard tries to speak for himself in the bouncy Augustan "Session of the Poets," but his "Arrogance made Apollo stark mad." And Jonathan Swift ironically laments, "From Flecknoe down to Howard's time, / How few have reach'd the low sublime!" ${ }^{14}$ His very name was toxic-Addison's Interesting Anecdotes records that Edward Howard, earl of Suffolk, dabbled in poetry, but says "that having the misfortune to be of the same name with the Honourable Edward Howard, so much ridiculed in the last age, no printer would meddle with his works." 15

Denigrations of Howard are not irrelevant to More's Utopia. Thomas More was at this time routinely praised as witty. Howard thought he himself was witty, but he was called dull. In an age of versifying "wits," to be dull is not so much to be boring as to be foolish, unable to balance fantasy with reason. How unlike More! Nobody thought him "dull." Utopia, for all its speculative radicalism, takes the form of a dialogue in which even the nonsense-speaking Hythloday expresses himself naturally, in good Latin, and Utopia itself is so strenuously reasonable that even when ridiculous it is rationally so. A man who prances around in feathers? (Were he a Utopian priest, this might make sense.) Another who kisses what he thinks is himself? This is not mimesis; this is not wit. One eighteenth-century critic, David Erskine Baker, says of Howard's "Heroick Nonsense" that it "must nauseate the most indulgent Spectator." The "Injudicious" might feel a "foolish Admiration of such Extravagance," but will not the critic perceive that "the Personages of the Drama [...] resemble no Characters in Nature, except, perhaps, the disordered Inhabitants of

12. The Complete Poems of John Wilmot, Earl of Rochester, ed. David M. Vieth (New Haven: Yale University Press, 1968), 144. “An Epistolary Essay” gives an ironic nod to Howard's British Princes (1669), which, says Vieth, "became a byword in the Restoration for bad poetry."

13. I quote the 1729 edition, p. 84.

14. "On Poetry: A Rhapsody," Jonathan Swift, ed. Angus Ross and David Wooley (Oxford: Oxford University Press, 1984), 544, lines 269-70. Swift is commenting on how, for the ambitious poet, there is "a difficulty still, / To purchase fame by writing ill."

15. Joseph Addison, Interesting Anecdotes, Memoirs, Allegories, Essays, and Poetical Fragments, Tending to Amuse the Fancy, and Inculcate Morality (London, 1797), 243. 
Bedlam?" 16 In such terms, More's Utopia is a radical but believable nowhere, not a hippogriff of idle invention like the fantasy monster in the real Orlando Furioso, for example, and whatever Utopia's utility in this play as a place to stash such silly fantasies as female rule.

Here I pause for some rebellious thoughts on utopias and fantasy, differing from those of some fine scholars. Utopia differs profoundly from such good but physically impossible places like the Land of Cockaigne and its precooked flying birds, Lucian's wine-filled brooks in his True History, the Oz Books in one of which packaged lunches grow on trees, or, in Woody Guthrie's day, the "Big Rock Candy Mountain"- the leftist parody of leftist hopes for the working class in which "there ain't no snow," there are "cigarette trees," "all the cops have wooden legs," the "hens lay soft boiled eggs," and "the little streams of alcohol come a-trickling down the rocks." Guthrie had been reading L. Frank Baum or maybe Lucian himself, and of course this is pure Land of Cockaigne, not Utopia. Utopias may indeed be impossible, but not because they violate the laws of physical nature as we know them in this world. Plato, More, and Bacon may dream idle dreams, but their dreams are politically and culturally improbable, not physically impossible. This scholar's beloved Hudson River, alas, will never run with Amstel Light or a good Merlot. Nor was More imagining a perfection, for much of Utopia is parody and reversal. We often forget the carnival aspect of Utopia, its dependence on being the opposite of England.

Howard's preface, however, is having none of what his critics say, and some readers might wonder if he had been reading Sir Philip Sidney's Apologie on poesis and the imagination. "[T]he wit and beauty of Poesy," declares Howard, "consist rather in manners feign'd" than in "vulgar [i.e., common] observation amongst men," although he understands that this play, "the humours of which are more remote and Satyrical," could not succeed in his own England. Yet his drama, he argues, is not utterly "remote" or novel. Some say female government is unallowably "new." But remember the Amazons; and women might in fact be capable of rule, "allowing for the disadvantage they have in not being suitably educated to letters." This play, moreover, confirms the "judgement and practice of the world in rendring them more properly the weaker sex." In other words, his play does not challenge the ordinary way of managing human affairs. Yes,

16. The Companion to the play-house (London, 1764), 1:xxxv. Baker omits Howard's first name, but I assume he means Edward, not Robert. 
his drama has some unlikely characters, says Howard, but England does suffer from liars such as Foppering, as well as from "the impossibilities pretended by Chymists" like those that poor self-infatuated Peacock seeks. In any case, "a Satyr cannot be poetically expressed but it must be highly Hyperbolical" - see, says Howard, Juvenal and Jonson.

What Howard does not do-aside from forgetting the great Elizabeth I, female ruler of England if with the heart and stomach of a king-is deploy his satire and setting to provoke thought about the best state of a commonwealth, about gender, or even about what the English are doing to Africans and what the Royal Society's seemingly silly science, here sillier even than extracting sunbeams from cucumbers, might eventually do for or to England. Howard refreshingly argues that his critics' definitions of satire are narrow; but he does not use his Utopia to query the newly dominant values more generally, although he does deploy it, very indirectly, to scoff at the Commonwealth. Reversing the body politic (deliciously if inadvertently symbolized in real life by having the British Republic's top legislative body at one point called the "Rump Parliament") has failed, and things are now put to rights. Howard's Utopia/ Commonwealth is no longer a mundus inversus, carnival or otherwise, and the sexes, like the politics, are once more rationally arranged-at least according to a royalist gentleman's understanding of reason. Peacock has shed his feathers, there will be no racially mixed marriage, and all is once more right side up. As More's fictionalized self in Utopia might put it (ironically or not), in both the play and in England the restored monarchy has "the nobility, magnificence, splendor and majesty" that most republics lack, and the monarch is, of course, male. ${ }^{17}$

And yet ... Howard's fantasy is not an utter perversion of More's Utopia, even if one can hardly make sense of Aphra Behn's claim in her prefatory poem that

This New Utopia rais'd by thee

Shall stand a Structure to be wonder'd at,

And men shall say this! This is he

Who that Poetick City did create,

17. I quote the objection of "Morus" to Utopia's communism. See Utopia, ed. Edward Surtz and J. H. Hexter, Complete Works 4 (New Haven: Yale University Press, 1965), 245. 
Of which Moor only did the Model draw

You did compleat that little world, and gave it Law. ${ }^{18}$

No, Mrs. Behn, Howard was not a better Thomas More, and his Utopia, even if for a while a "monstrous democracy," is laughably unlike Hythloday's island. And yet the royalist Howard, too, explores, if with bad memories of his own island's recent past, what it might mean to take a common form of powermen's over women-and upend it. His play's resolution, a hierarchical sharing of power by king and queen, is not likely to please even the most hesitant feminist, but his play, with its same/other and worrisome reversals, has a part in More's complex afterlife.

Some years later, it is worth recalling, came a new English translation of Utopia by Bishop Gilbert Burnet (1684) with a preface that helps explain the assumptions behind the denigrations of Howard's play as well as the political timidities of the play itself. Burnet says that because English has now divested itself of its recent "fulsome Pedantry" (humanist pickiness?), the "trifling way of dark and unintelligible wit" that followed (a slap at what we call the Metaphysical poets?), and the "extravagance of Canting that succeeded this" (so much for heated Puritan preachers), it is now time to retranslate a book "writ by one of the greatest Men that this Island has produced" and containing "many fine and well-digested Notions" (A3v-A4; A5v). More himself, says Burnet, could not have wished the "taking away of all Property, and the levelling the World," an aim that would now recall, to his readers' shuddering minds, the recent Commonwealth's Levellers and Diggers, and he does not so much advocate an impossible dream as "set many Notions in his Reader's way" (A6v). This is a refreshing recognition that Utopia is what George Logan, borrowing from the sci-fi writer Ursula LeGuin, who borrowed from modern physics, has called a "thought experiment"; but Burnet also makes Utopia comfortably safer, a reassuring thought for many in Restoration England, including the likes of

18. Behn's comparisons of Howard to Ben Jonson make more sense-and, as she says, this play does indeed mirror nature, "Since most of men Sir Graves, or Peacocks are" (a3). True enough, although few men in England wore feathers or made love to their clones. The other prefatory poems by Edward Ravenscroft and "J.T." also read Howard as another Jonson. Like Shadwell, who likewise attempted to revive humours comedy, Howard's failure may have been due in part to an approach that, whatever Restoration admiration for Jonson, seemed passé. The terms in which the play's failure is expressed give insight into Restoration and Augustan notions of wit. Six Days might have done better in, say, 1610. 
Edward Howard. ${ }^{19}$ Notions are fine, even provocative, and indeed, saying "I have a dream today" may send people marching in the streets tomorrow. Burnet is not wrong, then, yet he may make Utopia less dangerous than some of us would like it to be (and it is fascinating to track how the Latin res publica [republic, public thing, commonweal] is translated before and after Britain's revolutionary Commonwealth). Such work is at least a reminder that not all of us share the now almost universal definition of More's invention as a nowhere "perfection." This seems too pagan, and More's ironic suggestion may be that when Utopians become Christian they will move into the world of Erasmus's Praise of Folly and its own complex paradoxes - the two writers were close friends, and Utopia, an ironic and complex text, makes a fine companion volume to the likewise ironic and complex Folly. Burnet makes More too innocuous, but he has a good point: Utopia sets forth notions, not perfections, whatever our hopes and energies might make of those same notions.

Let me end, though, with one more minor-indeed, minimal-utopia, if merely to remind the reader (although this is hardly news) how useful More's invention could be even when an author is not exploring possible worlds but merely finding a helpful and safe setting for fantasy. Sometimes, that is, the Restoration or Augustan Utopia is both a non-place and a version of England. So is More's island, of course, and so are Hall's parodic 1605 Mundus Alter et Idem and Bullein's Nodnol. Anglo-Utopias (Britopias?) can be even less radically same/other, less disturbing than More's. Margaret Cavendish's 1666 Blazing World, for example, has a queen in the present, not a named and unelected king relegated to the remote past like Utopus, and her decrees are the Royal Society's real hopes, not the stuff of Orlando Curioso.

The short and curious Britopia with which I conclude, however, is not an imagined other world but an England translated into avian terms, an anonymous birdtopia: Canary-Birds naturaliz'd in Utopia. A Canto. Dulce est paternum solum (1709). At issue was an act of Parliament naturalizing foreign Protestants; some of the Utopian birds' arguments over immigration have a striking resemblance to those in modern America, Britain, Germany ... and elsewhere. The queen eagle rules that for the moment, at least, canaries fleeing

19. George Logan, The Meaning of More's “Utopia” (Princeton: Princeton University Press, 1983), 139n; this term, although originally from German philosophy, is used (as Logan notes) by the science fiction writer Ursula K. Le Guin; if usually applied to philosophy and science, it suits utopian experiments in the extrapolation of assumptions. 
that neighbour bird-nation ruled by a large bird who has suspended what little religious freedom they used to have (an allusion, of course, to Louis XIV's revocation of the Edict of Nantes) and given them the choice of becoming Catholic, being punished by death or hard labour, or fleeing to America, may nest in England and find safety. I hardly need spell out the horrible relevance to our own world.

In this verse satire, then, a feathery queen of Utopia has decreed that for the moment those foreign canaries who are still on the wing, hoping to escape their royal persecuting hawk, may perch in her kingdom. Now a Parliament of anxious Utopian birds meets to consider naturalizing those worrisomely numerous foreign canaries who have winged their way across water. Should they be naturalized or, rather, for the public good, should they be expelled? The refugee canaries at least claim to be of the right [i.e., Huguenot] faith, but some Utopian birds remain suspicious, and others object that these immigrants will take the Utopian birds' jobs and might soon overwhelm Utopian culture, to say nothing of seducing female native birds with their foreign prestige, their chic and savoir faire. As rebels to the hawk, they are also a political threat, suggests one nativist bird, "For is not Peoples na [t]'ral Temper, / In all Rebellions idem semper" [i.e., "always the same"]. ${ }^{20}$ If they revolt against the hawk, might they not later rebel against the Canary throne? The debate is eventually settled in the immigrants' favour by the queenly Eagle (presumably named Anne). Utopia can absorb French immigration and remain the good place-or Britain, as we would call it. But why Utopia? For fun? To deflect (or seem to) criticism? Because semi-satire can be more effective than diatribe or position papers?

What to conclude? Wimpishly (although More himself offers no conclusive pronouncement, merely an ambiguous evasive comment as he and the company head off to dinner), I leave that to the reader. I might stress, though, and with little originality, that from 1516 to modern computer games and neologisms (e.g., "Whitopia," a term coined by an African-American friend of mine for the world of white exurbs, or "Zootopia," a cartoon that startles some viewers with its scoffing atheism), More's invention has been not just a

20. Canary-Birds naturaliz'd in Utopia. A Canto. Dulce est paternum solum (London, [1709]; repr. 1717), 9. At issue was an act of Parliament naturalizing foreign Protestants; some of the Utopian birds' arguments over immigration have a striking resemblance to those in modern America. The eagle rules that for the moment, at least, Huguenot canaries still fleeing France after Louis XIV's revocation of the Edict of Nantes may nest in England. 
fantasy but a useful one, even if many think "utopia" a dream of perfection. Perhaps irony and quasi-parody of the known are less comfortable than fictional otherness. Noplace is easier to understand than is irony merged with semi-hopes, parody merged with possibilities. We can store various unrealities, good or bad or both or neither, in utopia's capacious nowhere; we can dream of turning its dreams into real somewheres-or usefully and gratefully avoid doing so. We can convert nowheres into wit, or into shudders, or ... but there is no limit, and often whether the nowhere is dream or nightmare might depend on whose angle of vision we adopt. After all, as an imaginative student of mine once showed in her collection of fictional letters from various figures in various utopias, 1984 makes as fine a world for Big Brother as the science-loving New Atlantis might be a site of horror for some math-hating English majors. And one can visit that lovely somewhere, Canada, to talk about various imaginary nowheres. Nowhere, utopia, is confusing-and possibly impossible, says modern physics-but it remains useful, even beautiful, even real. We can still dream, comfortingly—and perhaps helpfully. 